\title{
Time of Day Regulates Subcellular Trafficking, Tripartite Synaptic Localization, and Polyadenylation of the Astrocytic Fabp7 mRNA
}

\author{
Jason R. Gerstner, ${ }^{1}$ William M. Vanderheyden, ${ }^{2}$ Timothy LaVaute, ${ }^{3}$ Cara J. Westmark, ${ }^{3}$ Labib Rouhana, ${ }^{4}$ Allan I. Pack, ${ }^{1}$ \\ Marv Wickens, ${ }^{4}$ and Charles F. Landry ${ }^{5}$ \\ ${ }^{1}$ Center for Sleep and Circadian Neurobiology, University of Pennsylvania School of Medicine, Philadelphia, Pennsylvania 19104, ${ }^{2}$ Department of Anatomy \\ and Neurobiology, Washington University Medical School, St. Louis, Missouri 63110, ${ }^{3}$ Waisman Center, University of Wisconsin-Madison, Madison, \\ Wisconsin 53705-2280, ${ }^{4}$ Department of Biochemistry, University of Wisconsin, Madison, Wisconsin 53706, and ${ }^{5}$ Scarab Genomics, LLC, Madison, \\ Wisconsin 53713
}

The astrocyte brain fatty acid binding protein (Fabp7) has previously been shown to have a coordinated diurnal regulation of mRNA and protein throughout mouse brain, and an age-dependent decline in protein expression within synaptoneurosomal fractions. Mechanisms that control time-of-day changes in expression and trafficking Fabp7 to the perisynaptic process are not known. In this study, we confirmed an enrichment of Fabp7 mRNA and protein in the astrocytic perisynaptic compartment, and observed a diurnal change in the intracellular distribution of Fabp7 mRNA in molecular layers of hippocampus. Northern blotting revealed a coordinated time-of-daydependent oscillation for the Fabp7 mRNA poly(A) tail throughout murine brain. Cytoplasmic polyadenylation element-binding protein 1 (CPEB1) regulates subcellular trafficking and translation of synaptic plasticity-related mRNAs. Here we show that Fabp7 mRNA coimmunoprecipitated with CPEB1 from primary mouse astrocyte extracts, and its 3'UTR contains phylogenetically conserved cytoplasmic polyadenylation elements (CPEs) capable of regulating translation of reporter mRNAs during Xenopus oocyte maturation. Given that Fabp7 expression is confined to astrocytes and neural progenitors in adult mouse brain, the synchronized cycling pattern of Fabp7 mRNA is a novel discovery among known CPE-regulated transcripts. These results implicate circadian, sleep, and/or metabolic control of CPEB-mediated subcellular trafficking and localized translation of Fabp7 mRNA in the tripartite synapse of mammalian brain.

\section{Introduction}

Many behavioral and physiological processes exhibit diurnal control. Sleep propensity (Fuller et al., 2006), feeding (Saper, 2006), long-term potentiation (Harris and Teyler, 1983; Raghavan et al., 1999; Chaudhury et al., 2005), and memory formation (Chaudhury and Colwell, 2002; Lyons et al., 2005, 2006a,b; Lyons and Roman, 2009) follow diurnal rhythms. Circadian genes affect complex physiological manifestations in many organisms (Andretic et al., 1999; Garcia et al., 2000; Sarov-Blat et al., 2000; Abarca et al., 2002; Dudley et al., 2003; Sakai et al., 2004; McClung et al., 2005; Turek et al., 2005; Feillet et al., 2006; EckelMahan and Storm, 2009; Gerstner and Yin, 2010; Kondratova et

\footnotetext{
Received June 24, 2011; revised Nov. 9, 2011; accepted Dec. 12, 2011

Author contributions: J.R.G., W.M.V., T.L., C.J.W., L.R., M.W., and C.F.L. designed research; J.R.G., W.M.V., T.L., C.J.W., and L.R. performed research; J.R.G. and T.L. contributed unpublished reagents/analytic tools; J.R.G., W.M.V., T.L., L.R., A.I.P., and C.F.L. analyzed data; J.R.G., A.I.P., M.W., and C.F.L. wrote the paper.

This work was supported by National Institutes of Heath Grant DA13780 to C.F.L. L.R. is supported by National Science Foundation Minority Postdoctoral Research Fellowship 0804021. C.J.W. is supported by the FRAXA Research Foundation. J.R.G. is currently supported by National Institutes of Heath Grant T32 HL07713.

We thank Josh Smith and Sandra Splinter BonDurant and the University of Wisconsin-Madison Genome Center for expert qRT-PCR services. We thank Ben August at the University of Wisconsin Medical School Electron Microscope Facility for expert EM services. We thank Laura Roethe, Quentin Bremer, and Andrew Brienen for excellent technical assistance.

Correspondence should be addressed to Jason R. Gerstner at the above address. E-mail: gerstner@upenn.edu. DOI:10.1523/JNEUROSCI.3228-11.2012

Copyright $\odot 2012$ the authors $\quad 0270-6474 / 12 / 321383-12 \$ 15.00 / 0$
}

al., 2010), suggesting that clock molecules influence various plasticity and neurophysiological processes (Herzog, 2007; Roth and Sweatt, 2008; Eckel-Mahan and Storm, 2009; Gerstner et al., 2009; Gerstner and Yin, 2010; Masri and Sassone-Corsi, 2010). Here we focus on time-of-day control of brain fatty-acid binding protein (Fabp7). Fabp7 has a unique synchronized pattern of global diurnal expression in astrocytes (Gerstner et al., 2006, 2008), and Fabp7 knock-out mice have altered NMDA-receptordependent current responses and memory (Owada et al., 2006), indicating astrocyte Fabp7 expression is critical to normal neurophysiological mechanisms and behavior.

Astrocytes are a major player in brain plasticity (Halassa and Haydon, 2010), and modulate neurophysiological mechanisms, such as LTP and LTD (Nishiyama et al., 2002; Yang et al., 2003; Pascual et al., 2005), and homeostatic synaptic scaling (Panatier et al., 2006; Stellwagen and Malenka, 2006; Turrigiano, 2006). Astrocytes have been implicated in the regulation of complex behavior (Halassa and Haydon, 2010), such as circadian rhythms (Li et al., 2002; Suh and Jackson, 2007), sleep (Halassa et al., 2009a), and learning and memory (Nishiyama et al., 2002; Gibbs et al., 2006; Bracchi-Ricard et al., 2008; Gibbs and Hertz, 2008; Suzuki et al., 2011). Astrocytic adenosine contributes to sleep disruption of hippocampal-dependent memory and synaptic plasticity (Florian et al., 2011), and its release is controlled by the circadian clock (Marpegan et al., 2011). These data suggest astro- 
cytic cellular and molecular processes contribute significantly to linking behavioral and physiological processes.

Fabp7 is enriched near synapses. Its abundance in synaptoneurosomal fractions declines with age (Pu et al., 1999). We found Fabp7 abundance cycles in synaptoneurosomes, suggesting daily variations in trafficking machinery. One potential mechanism is through mRNA-binding proteins, such as cytoplasmic polyadenylation element (CPE)-binding protein (CPEB). One such protein, CPEB1, is present in astrocytes (Jones et al., 2008), but its role in targeting mRNAs to perisynaptic processes in astrocytes has not been explored. CPE-mediated mechanisms exist for trafficking and local translation of neuronal mRNAs, so we conducted a bioinformatic search that revealed phylogenetically conserved CPE sequences in Fabp7 mRNA. We hypothesized that Fabp7 CPEs are functional and able to mediate translation, predicting Fabp7 mRNA could undergo time-of-day subcellular translocation and polyadenylation. Our novel findings confirm that, in addition to neurons, cytoplasmic polyadenylation processes exist for astrocytic CPEcontaining mRNA (Jones et al., 2008) and establish the existence of coordinated control for mRNA trafficking and subsequent translation at the perisynaptic astrocytic process compartment across the day.

\section{Materials and Methods}

\section{Subjects and handling}

Male mice (C57BL/6) were either purchased directly from Harlan Sprague Dawley (adult) or taken at specific ages from a breeding colony. Animals were entrained to a $12 \mathrm{~h}$ light, $12 \mathrm{~h}$ dark (12:12) schedule for a minimum of 2 weeks. Zeitgeber time (ZT) 0 was lights-on, and ZT12 was lights-off, on this diurnal schedule. For tissue collection, animals were killed by decapitation, their brains dissected, flash frozen at $-30^{\circ} \mathrm{C}$ in 2-methylbutane, and stored at $-80^{\circ} \mathrm{C}$. For tissue punches of specific regions, brains were embedded in optimal cutting temperature media and sectioned on a Leica $(\mathrm{CM} 3050)$ cryostat at $-25^{\circ} \mathrm{C}$ as previously described (Gerstner et al., 2006, 2008). Punches from the same brain region were pooled from each of the animals within the same group, and stored at $-80^{\circ} \mathrm{C}$ until RNA isolation. All animal care and use procedures were in strict accordance with University of Wisconsin Institutional Animal Care and Use Committee and National Institutes of Health guidelines for the humane treatment of laboratory animals.

\section{Synaptoneurosome preparation}

Synaptoneurosomes (SNs) were prepared from mouse whole brain as described previously (Westmark and Malter, 2007; Westmark et al., 2011). Briefly, mice were asphyxiated with carbon dioxide followed by removal of the brain. Brains were washed in ice-cold gradient medium (GM) buffer (0.25 м sucrose, $5 \mathrm{~mm}$ Tris, pH 7.5, and 0.1 mM EDTA), transferred to a glass Dounce homogenizer containing ice-cold GM buffer, and gently homogenized with five strokes of the loose pestle followed by five strokes of the tight pestle. The homogenate was spun at $1000 \mathrm{~g}$ for $10 \mathrm{~min}$ at $4^{\circ} \mathrm{C}$ in round-bottom tubes to pellet cellular debris and nuclei. The supernatant ( $2 \mathrm{ml}$ of aliquots) was applied to Percoll gradients (layers, $2 \mathrm{ml}$ each of $23 \%, 15 \%, 10 \%$, and $3 \%$ isomotic Percoll) and spun at speed $(32,500 \mathrm{~g})$ for $5 \mathrm{~min}$ at $4^{\circ} \mathrm{C}$. The third band from the top of the gradient $(23 \%-15 \%$ interface) containing intact $\mathrm{SNs}$ was removed and pooled for the experiments.

\section{Immunocytochemistry and electron microscopy}

Animals were perfused through the heart with $0.1 \%$ heparin in $0.01 \mathrm{M}$ PBS, pH 7.4, until liver cleared, followed by $2 \%$ paraformaldehyde, $1 \%$ glutaraldehyde in $0.1 \mathrm{~m}$ phosphate buffer (PB), pH 7.4. Sections were cut at $50 \mu \mathrm{m}$ on a vibratome and stored in $0.01 \mathrm{M}$ PBS and $0.01 \%$ azide solutions until processing. The hippocampal section was prepared from a mouse killed at ZT12.

Following fixation, the slices were rinsed in $0.1 \mathrm{M} \mathrm{PB}$ and then treated with freshly prepared $0.1 \%$ sodium borohydride in $0.1 \mathrm{M} \mathrm{PB}$ for $10 \mathrm{~min}$ to quench unbound aldehydes. Next, the slices were permeabilized for 30 min with $0.1 \%$ Triton X-100 in PBS followed by three 10 min rinses in PBS. The slices were then blocked for nonspecific antibody binding with Aurion goat-blocking agent (Cat. \#25596, containing 5\% BSA, $0.1 \%$ cold water fish gelatin, and 5\% normal goat serum in PBS, pH 7.4) for $30 \mathrm{~min}$. The slices were then rinsed three times for $10 \mathrm{~min}$ each in incubation buffer containing PBS $+0.1 \%$ BSA-C (Aurion Immuno Gold Reagents, Cat. \#25558). Finally, the samples were incubated in a mixture of incubation buffer and rabbit primary Fabp7 antibody (Millipore) at a dilution of 1:1000 overnight at $4^{\circ} \mathrm{C}$. The following day, the slices were rinsed in incubation buffer every $10 \mathrm{~min}$ for $2 \mathrm{~h}$ (12 rinses total), and then incubated overnight in a 1:100 dilution of ultrasmall gold conjugate $\left[\mathrm{F}\left(\mathrm{ab}^{\prime}\right) 2\right.$ fragment of goat-anti-rabbit IgG (heavy and light chains), Aurion Immuno Gold Reagents, Cat. \#25360] at $4^{\circ} \mathrm{C}$. After the overnight incubation, the slices were rinsed in incubation buffer $6 \times$ for $10 \mathrm{~min}$ each, and then rinsed in PBS $6 \times$ for 5 min each. The slices were postfixed in $2 \%$ glutaraldehyde in $0.1 \mathrm{M} \mathrm{PB}$ for $30 \mathrm{~min}$ and rinsed $2 \times$ for 5 min each in $\mathrm{PB}$.

The use of ultrasmall gold conjugates requires a silver-enhancing step to increase the size of the subnanometer gold particles to more easily visualize the particles by transmission electron microscopy. After postfixation, the slices were rinsed $3 \times$ for 10 min each in Enhancing Conditioning Solution (ECS) (Aurion). Next, the slices were developed in Silver Enhancement Solution (Aurion) for $1.25 \mathrm{~h}$. To terminate silver enhancement, the slices were exposed to a solution of $0.3 \mathrm{~m}$ sodium thiosulfate in ECS for $5 \mathrm{~min}$. The slices were then rinsed twice in $10 \mathrm{~min}$ intervals in ECS and finally processed routinely for electron microscopy.

After silver enhancing, the slices were fixed in a solution of $0.5 \%$ osmium tetroxide in $0.1 \mathrm{M} \mathrm{PB}$ for $30 \mathrm{~min}$. Following $\mathrm{OsO}_{4}$ postfixation, the samples were dehydrated in a graded ethanol series, then further dehydrated in propylene oxide and flat-embedded in Epon epoxy resin. The specific regions used for the analysis were trimmed from the flatembedded sections and flat-mounted on blank epoxy resin stubs. Excess epoxy resin was then sectioned away in $1 \mu \mathrm{m}$ increments with a Diatome Histo diamond knife using a Reichert-Jung Ultracut-E ultramicrotome until the surface of the tissue was exposed. Samples were then sectioned using a Diatome Ultra 45 diamond knife with the same microtome and contrasted with Reynolds lead citrate and 8\% uranyl acetate in 50\% EtOH. Ultrathin sections were observed with a Philips CM120 electron microscope and images were captured with a MegaView III sidemounted digital camera.

\section{Northern blot analysis}

Northern blotting was performed as described previously (Gerstner et al., 2006). Briefly, brains were dissected and total RNA was isolated using TRIzol (Invitrogen), according to the manufacturer's specifications, and stored at $-80^{\circ} \mathrm{C}$. Before loading, each sample was incubated with sample buffer $[7.5 \%$ formaldehyde, $43 \%$ formamide, $12 \% \quad 10 \times 3-(\mathrm{N}-$ morpholino)propanesulfonic acid, $0.12 \%$ ethidium bromide] for $5 \mathrm{~min}$ at $56^{\circ} \mathrm{C}$, and then cooled on ice for $5 \mathrm{~min}$. Northern blots consisted of 1 $\mu \mathrm{g}$ of total RNA per lane and were electrophoresed on a $1.2 \%$ agarose gel. RNA was transferred overnight onto a sheet of GeneScreen Plus nitrocellulose (NEN Life Science Products). DNA templates generated by PCR were labeled with ${ }^{32} \mathrm{P}$ using the Megaprime DNA labeling system (GE Healthcare). The following primers were used: Fabp7 forward primer, AGACCCGAGTTCCTCCAGTT, reverse primer, CCTCCACACCGA AGACAAAC, Cpeb1 forward primer, CATCTTGGGACCTTCTTGGA, Cpeb1 reverse primer, AAGACCCAAGGGATTACC, Cpeb2 forward primer, GGTCGCTCTTCCCTATTTCC, Cpeb2 reverse primer, TCCA AAGGCTGAGAACCATC, Cpeb3 forward primer, CCCTTCTCCAGC AATGTGAT, Cpeb3 reverse primer, CTCGTTCCCCATTTTGACAT, Cpeb4 forward primer, CCTCACTGCTTCACTCACCA, Cpeb4 reverse primer, AACAAAGCGGGCACTGATAG. Probes were mixed with hybrisol and incubated overnight at $42^{\circ} \mathrm{C}$. Blots were washed $3 \times$ with 100 $\mathrm{ml}$ of $2 \times \mathrm{SSC}, 1 \% \mathrm{SDS}$, at room temperature, then twice for $30 \mathrm{~min}$ each with $100 \mathrm{ml}$ of $2 \times \mathrm{SSC}, 1 \% \mathrm{SDS}$, at $50^{\circ} \mathrm{C}$, and finally once for $30 \mathrm{~min}$ with $100 \mathrm{ml}$ of $0.5 \times \mathrm{SSC}, 1 \% \mathrm{SDS}$, at $60^{\circ} \mathrm{C}$. Following washes, blots were exposed to a phosphoscreen for $3 \mathrm{~d}$ and image analysis was performed using the Storm 860 and ImageQuant 5.2 software (Molecular Dynamics). A 983 bp PCR product for glyceraldehyde-3-phosphate dehydroge- 
nase (GAPDH) was generated as described previously (Gerstner et al., 2006).

\section{RNase $H$ and poly (A) analysis}

The RNase $\mathrm{H}$ digestion procedure was modified from previously published methods (Goodwin and Rottman, 1992). Briefly, $5 \mu \mathrm{g}$ of total RNA was incubated at $80^{\circ} \mathrm{C}$ for $10 \mathrm{~min}$, rapid cooled to $20^{\circ} \mathrm{C}$, and combined with or without $0.15 \mu \mathrm{g}$ of Oligo-dT $\mathrm{d}_{(12-18)}$ in $1 \mu \mathrm{M}$ EDTA for 15 min. The addition of $50 \mathrm{U}$ RNase $\mathrm{H}$ (Promega) was added to RNase $\mathrm{H}$ buffer (20 mм HEPES-KOH, pH 7.8, $50 \mathrm{~mm} \mathrm{KCl,} 10 \mathrm{~mm} \mathrm{MgCl}_{2}$ ) at a final volume of $50 \mu \mathrm{l}$, and digested at $37^{\circ} \mathrm{C}$ for $30 \mathrm{~min}$. RNA was isolated from the reactions by phenol-chloroform extraction, ethanol was precipitated, and Northern blotting was performed as above.

Densitometric analysis of the poly(A) tail was performed using ImageQuant software. Briefly, a $1 \times 3$ pixel window (i.e., the width of a lane in the Northern blot $\times 3$ pixel window) was generated, and the starting spot was determined at ZT 12 by the lane that contained the time point with the lowest poly(A) tail size. The starting spot within this lane was located above the resolved band with a signal intensity value nearest the background value. This height on the gel was determined to be the starting spot across all lanes. Identical boxes were placed at this level in adjacent lanes for all ZT time points, and a signal intensity value was determined within each box. The boxes were then moved up a single pixel, and the new signal intensities tabulated (single rung). Signal intensity values for each rung were done repeatedly until the lane with the last value closest to the background value was tabulated (equal to longest poly(A) tail). Tabulated values for each rung were averaged, and this value was used to generate a normalized value across all time points within a given single rung. These normalized values within a given time point were averaged across all rungs to control for relative signal intensity. This normalization controls for time-of-day changes in transcript intensity of the band, but retains a signal above noise/background for calculating band length.

\section{Quantitative reverse transcriptase PCR}

All quantitative reverse transcriptase PCR (qRT-PCR) was performed at the University of Wisconsin-Madison Genome Center. Complementary DNA was generated using Superscript II Reverse Transcriptase (SSRII; Invitrogen) as follows: $5 \mu \mathrm{g}$ of total RNA was added to 100 pmol of T7 oligo-dT primer [GGCCAGTGAATTGTAATACGACTCACTATAGG GAGGCGG-d(T)24] and the reaction volume was brought to $12 \mu \mathrm{l}$ of total volume with PCR grade water. The reaction was incubated at $70^{\circ} \mathrm{C}$ for $10 \mathrm{~min}$ in a Mastercycler ep thermocycler (Eppendorf) and placed on ice for $2 \mathrm{~min}$. Five times SSRII buffer $(4 \mu \mathrm{l}), 2 \mu \mathrm{l}$ of $0.1 \mathrm{~m}$ DTT, and $1 \mu \mathrm{l}$ of $10 \mathrm{~mm}$ deoxyribonucleotide triphosphates were added and the reaction was incubated in a thermocycler for $2 \mathrm{~min}$ at $42^{\circ} \mathrm{C}$. After incubation, $1 \mu \mathrm{l}$ of SSRII was added and the reaction was incubated at $42^{\circ} \mathrm{C}$ for $1 \mathrm{~h}$. CDNA was then quantified using an ND-1000 Spectrophotometer (NanoDrop Technologies) and normalized to $20 \mathrm{ng} / \mu \mathrm{l}$ with PCR grade water.

\section{PCR methods}

Individual reactions contained $1 \times$ Probes MasterMix (F. Hoffmann-La Roche), 0.05 U uracil-N-glycosylase, $1 \times$ LCGreen Plus (Idaho Technology), $200 \mathrm{~nm}$ each primer, and $20 \mathrm{ng}$ of cDNA. The following primers were used: Fabp7 forward primer, CTCTGGGCGTGGGCTTT, reverse primer, TTCCTGACTGATAATCACAGTTGGTT, $\beta 2 \mathrm{M}$ forward primer, CATGGCTCGCTCGGTGACC, $\beta 2 \mathrm{M}$ reverse primer, AATGTG AGGCGGGTGGAACTG, $\beta$-actin forward primer, AGAGGGAAATCG TGCGTGAC, $\beta$-actin reverse primer, CAATAGTGATGACCTGGCCG T, GAPDH forward primer, CATGGCCTTCCGTGTTCCTA, GAPDH reverse primer, ATGCCTGCTTCACCACCTTCT. The total reaction volume of $5 \mu \mathrm{l}$ was overlaid with $10 \mu$ of Chillout Wax (Bio-Rad Laboratories). All reactions were run on a LightCycler 480 Real-Time PCR System (F. Hoffmann-La Roche). The cycling parameters were $50^{\circ} \mathrm{C}$ for 5 min, $95^{\circ} \mathrm{C}$ for $10 \mathrm{~min}$, and then 50 cycles of $95^{\circ} \mathrm{C}$ for $15 \mathrm{~s}$ and $60^{\circ} \mathrm{C}$ for $30 \mathrm{~s}$. Fluorescence data were collected at a wavelength setting of $450-500$ $\mathrm{nm}$. Analysis was performed using both LightCycler 480 proprietary software and qBASE v1.3.5 (Jan Hellemans, Center for Medical Genetics, Ghent University, Belgium).

\section{In situ hybridization}

In situ hybridization was performed as previously described (Gerstner and Landry, 2007). Briefly, postfixed, cryostat sections $(20 \mu \mathrm{m})$ were pretreated with proteinase $\mathrm{K}(0.2 \mu \mathrm{g} / \mathrm{ml}$; Promega $)$ and hybridized overnight at $55^{\circ} \mathrm{C}$ in $150 \mu \mathrm{l}$ of ${ }^{35} \mathrm{~S}$-labeled antisense riboprobe $(10,000 \mathrm{cpm} /$ $\mu \mathrm{l})$. Following posthybridization washes, sections were exposed to a phosphoscreen for $6 \mathrm{~d}$. Image analysis was performed using the Storm 860 and ImageQuant 5.2 software (Molecular Dynamics). For densitometric analysis of in situ hybridization data, specific regions from a minimum of four sections were averaged per animal per time point, and normalized to background as described previously (Gerstner and Landry, 2007).

Antisense ( ${ }^{35} \mathrm{~S}$-labeled) was made from Fabp7 PCR templates derived from T7-tagged reverse or forward primers, respectively. The following primers were used: Forward primer: AGACCCGAGTTCCTCCAGTT, reverse primer, CCTCCACACCGAAGACAAAC. Fabp7 template used for in vitro transcription was generated using standard PCR conditions. T7 sequence tag extending the reverse primer was GGCCAGTGAATTGT AATACGACTCACTATAGGGAGGCGG. In vitro transcription reactions were performed as described by Promega Biotech.

For emulsion autoradiography, sections processed for in situ hybridization (ISH) were dipped in NTB 3 liquid emulsion (Eastman Kodak) under safelight conditions and stored at $4^{\circ} \mathrm{C}$ for 6 weeks. Processing was as described by the manufacturer. For analysis of diurnal time points, all sections within a series were processed under identical conditions in the same run $(N=2-5$ animals per group). Images of ISH emulsion-dipped hippocampal sections were taken using darkfield microscopy, and saved as Tagged Image File Format (TIFF) files for analysis. The region of hippocampus was analyzed using ImageJ software (National Institutes of Health) extending from interaural plane 1.62 to $2.22 \mathrm{~mm}$ as defined by Paxinos and Franklin (2003). Counts were tabulated, background was subtracted, and averaged. Briefly, a standardized $\sim 230 \times 230 \mu \mathrm{m}$ box was made that covered the precursor layer and extended through the granular cell layer and into the molecular layer of the dentate gyrus of the hippocampus. Each individual animal had $\sim 4$ sections that were analyzed per time point and these were then averaged to generate a single number that was used as an $N=1$. Final counts for each time point were calculated by averaging across all animals in each group. Density measures were used to calculate distribution of silver grains by normalizing signal intensity values of the molecular layer against the highest average background-subtracted value within the $230 \times 230 \mu \mathrm{m}$ box. These silver grain distribution values (background-subtracted pixel counts per maximal pixel count) were then averaged and divided by the square area $\left(\mu \mathrm{m}^{2}\right)$ analyzed. Individual samples were averaged within groups, plotted with SEM bars, and subjected to ANOVA statistical analysis.

\section{Western blotting}

Samples prepared from whole brain were subjected to SDS-PAGE by separating $10 \mu \mathrm{g}$ of protein per lane on a $10-20 \%$ gradient precast gel (Biorad). Protein was transferred to $0.2 \mu \mathrm{m}$ Protran nitrocellulose membranes (PerkinElmer), blocked in 5\% dried milk powder in $50 \mathrm{~mm}$ Tris$\mathrm{HCl}, \mathrm{pH}$ 7.5, $15 \mathrm{~mm} \mathrm{NaCl}, 0.5 \%$ Tween-20 (TBST), washed briefly in TBST and incubated in primary antibody in TBST overnight at $4^{\circ} \mathrm{C}$. Fabp7 antibody (Millipore) was used at 1:1000 dilution in TBST; antibody to $\beta$-actin (Imgenex) was used at 1:10,000 dilution; and antiglyceraldehyde-3-phosphate dehydrogenase (Imgenex) was used at 1:5000 dilution. Blots were then washed three times in TBST, incubated for $1 \mathrm{~h}$ in antirabbit horseradish peroxidase-conjugated secondary antibody (1:7500 in TBST; KPL), washed three times in TBST and incubated in ECL plus Western blotting detection reagent for 5 min based on the manufacturer's instructions (GE Healthcare). For time-of-day synaptoneurosomal blots, Fabp7 antibody was used at 1:2000 dilution, PSD-95 (MAB1598, Millipore) was used at 1:1000, and normalization to total protein was evaluated on the same blots using India ink (Higgins Black Magic, No. 44011). Visualization was performed by chemoluminescence scanning (medium sensitivity, photomultiplier voltage, $600 \mathrm{~V}$ ) on a Typhoon 9410 PhosphorImager (GE Healthcare). Densitometric analysis was performed using ImageQuant version 5.2. 


\section{Tissue culture}

Dissociated primary cortical astrocyte culture tissue was a gift from the laboratory of Dr. Dandan Sun (University of WisconsinMadison) and prepared as described previously (Su et al., 2002). Briefly, cerebral cortices were removed from 1-d-old mice. The cortices were incubated in a solution of $0.25 \mathrm{mg}$ of trypsin per milliliter of HBSS for $25 \mathrm{~min}$ at $37^{\circ} \mathrm{C}$. The tissue was then mechanically triturated and filtered through nylon meshes. The dissociated cells were rinsed and resuspended in Eagle's minimal essential medium (EMEM) containing $10 \%$ fetal bovine serum. Viable cells $(1 \times 104$ cells per well $)$ were plated in 24-well plates coated with collagen type 1 . Cultures were maintained in a $5 \% \mathrm{CO}_{2}$ atmosphere at $37^{\circ} \mathrm{C}$. To obtain morphologically differentiated astrocytes, confluent cultures (days 12-15 in culture) were treated with EMEM containing $0.25 \mathrm{~mm}$ dibutyryl cAMP (DBcAMP) for $7 \mathrm{~d}$ to induce differentiation.

\section{Immunoprecipitation}

To assess the relative binding of Fabp7 mRNA to CPEB, coimmunoprecipitation experiments were done according to those previously described by Brown et al. (2001). Briefly, mouse brain astrocyte culture was lyzed in $1 \mathrm{ml}$ of ice-cold buffer (10 mM HEPES, pH 7.4, $200 \mathrm{~mm} \mathrm{NaCl}, 30$ mM EDTA, and $0.5 \%$ Triton X-100) with $2 \times$ complete protease inhibitors (Boehringer Mannheim) and $400 \mathrm{U} / \mathrm{ml}$ RNasin (Promega). Nuclei were pelleted, the supernatant was precleared, and an aliquot (20\%) of this precleared supernatant ("input") was saved for RNA extraction. The remaining lysate was immunoprecipitated with anti-CPEB antibody (Affinity BioReagents). The immunoprecipitate was resuspended in DEPCtreated water for protein analysis and RNA extraction.

\section{Xenopus oocyte maturation assay}

Reporter constructs. The $277 \mathrm{nt}$ long Fabp7 3'UTR cDNA sequence (as in NCBI accession no. BC055280) was directionally cloned downstream of the luciferase open reading frame in pLuci-XlGLD-2A(S) (Rouhana and Wickens, 2007) using XhoI and SpeI restriction endonucleases. For mutational analysis of the Fabp7 3'UTR, sense and antisense oligonucleotides corresponding to the last $100 \mathrm{nt}$ of the Fabp7 3'UTR wild-type sequence and mutations (3XCPE mutant and hexanucleotide mutant) were synthesized (Integrated DNA Technologies), annealed, and ligated downstream of the luciferase ORF as above. Control constructs for Gld-2 have been previously described (Rouhana and Wickens, 2007), as have the construct used for transcription of $\beta$-galatosidase mRNA (Gray et al., 2000).

In vitro transcription of capped reporter mRNAs. DNA templates were linearized with SpeI or BamHI and used as substrate for transcription of capped mRNAs using Megascript T7 RNA polymerase (Ambion) in the presence of $6 \mathrm{~mm}$ m7GpppG (New England Biolabs). Transcripts were DNase treated, ethanol precipitated, and resuspended in RNase-free water.

Injection of mRNA and manipulation of Xenopus oocytes. Oocyte removal, injection, and the induction of meiotic maturation were performed as previously described (Ballantyne et al., 1997) with the following minor modifications. MRNAs were injected at $\sim 2-3 \mathrm{fmol}$ of the luciferase reporter mRNA, along with $12 \mathrm{fmol}$ of $\beta$-gal reporter mRNA in $50 \mathrm{~nL}$ of RNase-free water. Oocytes were then allowed to recover for $2 \mathrm{~h}$ and left intact or stimulated for meiotic maturation with $10 \mu \mathrm{g} / \mathrm{ml}$ of progesterone overnight at room temperature, except for time points indicated in Figure $5 C$.

Luciferase and $\beta$-galactosidase measuring assay. Groups of five oocytes were pooled and analyzed for luciferase and $\beta$-galactosidase activity as previously described (Gray et al., 2000).

\section{Results \\ Location \\ Fabp7 tripartite synapse enrichment}

The localization of Fabp7 in the mammalian adult CNS is not well characterized. One previous study described the decline of both Fabp7 and Fabp3 protein abundance within brain synapstosomal fractions of aged mice (Pu et al., 1999). Because Fabp7 knock-out mice have been shown to influence NMDA-receptor-
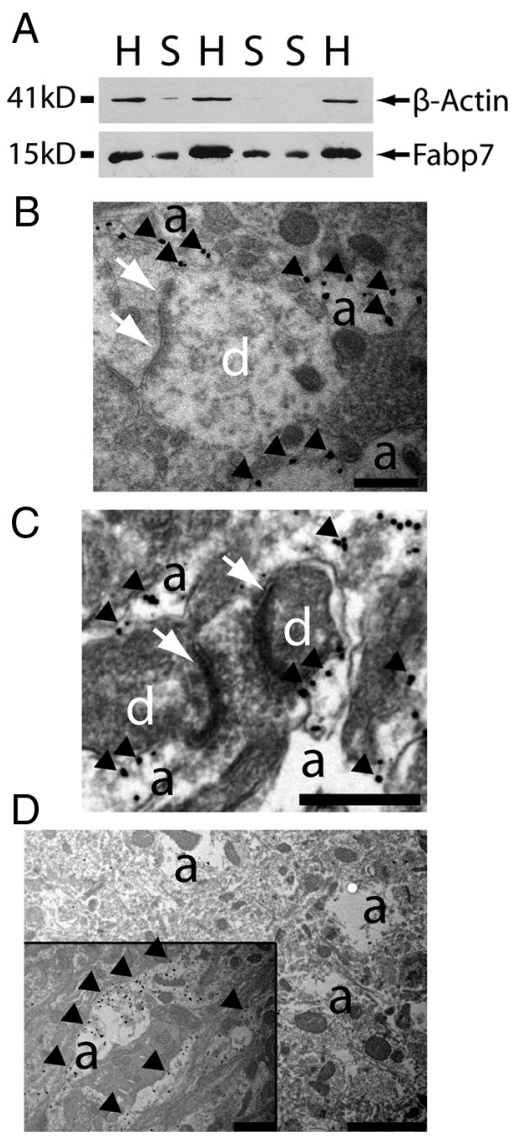

Figure 1. Fabp7 is enriched in the perisynaptic process compartment. $\boldsymbol{A}$, Western blot analysis of protein isolated from mouse brain total homogenate $(\mathrm{H})$ or synaptoneurosome $(\mathrm{S})$ fractions shows an abundance of Fabp7 protein compared with $\beta$-actin. $\boldsymbol{B}, \boldsymbol{C}$, Electron microscopy of nerve terminals in $(\boldsymbol{B})$ hippocampus and $(\boldsymbol{C})$ cerebellum revealed the presence of nanogoldlabeled Fabp7 immunoreactive particles (filled arrowheads) in the perisynapstic compartment of astrocyte processes (a). White arrows point to the synaptic density; dendrites (d). Scale bars, $500 \mathrm{~nm}$. D, Electron microscopic image of background labeling of nanogold-treated sections lacking Fabp7 primary antibody. Scale bar, $2 \mu \mathrm{m}$; astrocyte (a). Inset: electron microscopic image of astrocyte-specific labeling of nanogold-treated sections with Fabp7 primary antibody for comparison to background. Note the concentration of nanogold particles (filled arrowheads) in astrocytes (a). Scale bar, $1 \mu \mathrm{m}$.

dependent physiology and memory behavior (Owada et al., 2006), we decided to examine Fabp7 synaptic localization in further detail. A significant enrichment of Fabp7 protein was observed in whole brain synaptoneurosomal fractions compared with $\beta$-actin ( $t$ test, $p<0.05, N=3$ ) as measured by Western blot (Fig. 1A), confirming its presence in synaptic preparations as previously reported (Pu et al., 1999). Since Fabp7 protein expression is confined to astrocytes and neural progenitors in adult mammalian brain, this suggests that it is enriched within the perisynaptic compartment of fine astrocytic processes that surround synapses, which together comprise the tripartite synapse (Halassa et al., 2007). We validated the presence of Fabp7 protein in the tripartite synapse using electron microscopy (EM) following immunocytochemistry on mouse brain tissue sections. Analysis of nanogold-labeled anti-Fabp7 immunoreactive (IR) protein with EM showed a clear localization of the IR product in the fine glial processes of hippocampal (Fig. $1 B$ ) and cerebellellar tripartite synapses (Fig. 1C). Fabp7 IR was not observed in neuronal compartments and nanogold labeling was nonspecific in control sections lacking primary Fabp7 antibody (Fig. 1D). 

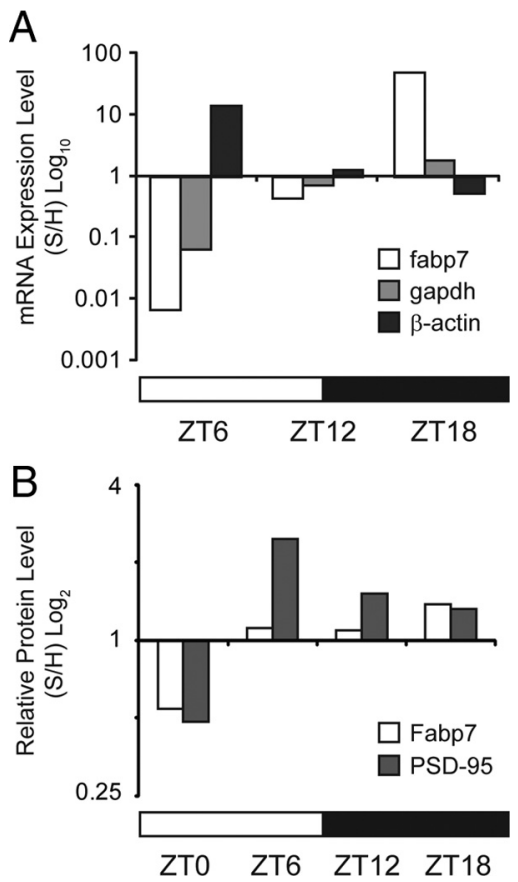

Figure 2. Fabp7 mRNA and protein enrichment cycles in the tripartite synapse. $\boldsymbol{A}$, Analysis of mouse whole-brain mRNA by qPCR shows a dramatic change in the ratio of synaptoneurosomal (S) to total homogenate $(H)$ Fabp7 mRNA compared with GAPDH and $\beta$-actin mRNA across the day. $\boldsymbol{B}$, Analysis of mouse brain protein also shows a time-of-day cycling of Fabp7 enrichment in the ratio of synaptoneurosomal $(S)$ to total homogenate $(H)$. The cycling of the synaptic protein PSD-95 is also observed, but in a different phase to Fabp7. Light bars, light period; dark bars, dark period.

Fabp7 mRNA and protein enrichment cycles in tripartite synapses Circadian cycling of core clock components and clock-controlled genes are well known in terms of transcriptional autoregulatory processing in the nuclear compartment of cells. In contrast, very little is known about time-of-day changes of cycling molecules in other cellular locations, including the synapses in brain. We therefore examined the localization of Fabp7 mRNA in synaptoneurosomal fractions over the light/dark cycle. We observed dramatic time-of-day changes in Fabp7 mRNA in synaptoneurosomal fractions compared with total homogenate, with higher levels in the synaptoneurosome during the dark phase compared with the light phase (Fig. $2 A$ ). We also observed diurnal changes in GAPDH and $\beta$-actin mRNA expression in synaptoneurosomal fractions compared with total homogenate. However, these differences did not compare with the $\sim 1000$-fold time-of-day differences observed for Fabp7. We next examined whether time of day changes Fabp7 protein levels in synaptneurosomes. We observed $>2$-fold changes in the relative abundance of Fabp7 protein in synaptoneurosomal fractions compared with total homogenate (Fig. $2 \mathrm{~B}$ ). Since $\beta$-actin protein is not as enriched in the synaptoneurosomal fraction as Fabp7 (Fig. 1), and since $\beta$-actin mRNA abundance cycles in the opposite direction as Fabp7 mRNA (Fig. 2A), we compared relative Fabp7 protein levels in synaptoneurosomes to the postsynaptic density protein 95 (PSD-95), a member of the membrane-associated guanylate kinase family that aids in receptor and ion channel clustering at synapses. We observed $>4$-fold changes in the relative abundance of PSD-95 protein in synaptoneurosome versus total homogenate (Fig. 2 B), with lower levels at lights on (ZT0). PSD-95 was more enriched in synaptic fractions at ZT6 and ZT12, and the ratio of its relative abundance in synaptoneurosomal versus total homogenate was similar to the ratio of Fabp7 at ZT0 and ZT18. Together, these data show that there are dynamic time-of-dayregulated changes in the relative levels of Fabp7 mRNA and protein in synaptic compartments.

Fabp7 mRNA is trafficked in adult hippocampus Previously, we have shown that time-of-day oscillations in Fabp7 mRNA abundance occur broadly throughout murine brain, including various layers of adult murine hippocampus (Gerstner et al., 2008). Given that Fabp7 protein is enriched in perisynaptic processes of astrocytes, and that Fabp7 mRNA is increased in the hippocampus following intense neuronal stimulation (Owada et al., 2006), we more closely examined circadian changes of Fabp7 mRNA in hippocampus. We specifically determined whether there is a time-of-day change on the distribution pattern of mRNA in molecular layers of the hippocampus. A more focal distribution of Fabp7 mRNA near astroglial somata would suggest recently synthesized transcript from the nucleus, whereas a more scattered distribution would reflect mRNA trafficking away from the cell body into the cytoplasm of astrocyte processes. Previously we reported significant time-of-day changes in Fabp7 mRNA levels in various brain regions of mouse brain (Gerstner et al., 2006, 2008). Quantification of Fabp7 mRNA by in situ hybridization using radio-labeled antisense riboprobes on this tissue subjected to liquid emulsion in the dentate gyrus of hippocampus revealed a significant time-of-day change in mRNA levels with peak levels of expression observed at ZT0 and ZT6 (Gerstner et al., 2008), in phase with other brain regions (Gerstner et al., 2006, 2008). We next examined the density of silver grains over the light/dark cycle to determine whether diurnal changes exist in histological localization for Fabp7 mRNA. Dispersal of silver grains is greater at the light/dark transition (ZT12), compared with a less distributed pattern between ZT0 and ZT6 (Fig. 3A,B). Analysis of silver grain density shows statistically significant difference in mRNA distribution based on time of day (one-way ANOVA, $p=0.0156$; Fig. $3 B$ ). The more somatic and punctate distribution observed at the ZT0-6 time period (Fig. 3A) corresponds with times of higher mRNA levels in the hippocampus (Gerstner et al., 2008), likely reflecting localization of recently transcribed Fabp7 mRNA in the cell bodies of astrocytes (Gerstner et al., 2008). Changes in the temporal distribution of Fabp7 mRNA were not specific to hippocampus. Similar patterns of Fabp7 mRNA localization were observed in other brain regions, such as the cortex, thalamus, amygdala, and hypothalamus (data not shown). Together, these data indicate a coordinated process in directed Fabp7 mRNA trafficking throughout brain.

\section{CPEB machinery}

Phylogenetic conservation of CPE sequences in the Fabp7 3' UTR CPEs represent one mechanism that controls trafficking of mRNA in neurons. The CPEs interact with CPEB1 within neurons following increased activity to regulate experience-dependent local translation (Wu et al., 1998). CPEB1 has also been shown to operate on $\beta$-catenin mRNA in astrocytes to regulate translation and subsequent migration (Jones et al., 2008). Given the diurnal changes in tripartite synaptic enrichment and trafficking observed in Fabp7 mRNA, we first bioinformatically searched for cis-acting elements within the $3^{\prime} \mathrm{UTR}$ that are involved in signaling pathways known to influence trafficking and synaptic targeting. The consensus CPE sequence UUUUAU and likely similar elements were therefore bioinformatically searched in the Fabp7 mRNA 3'UTR of various species. Multiple phylogenetically conserved CPEs were ob- 
A

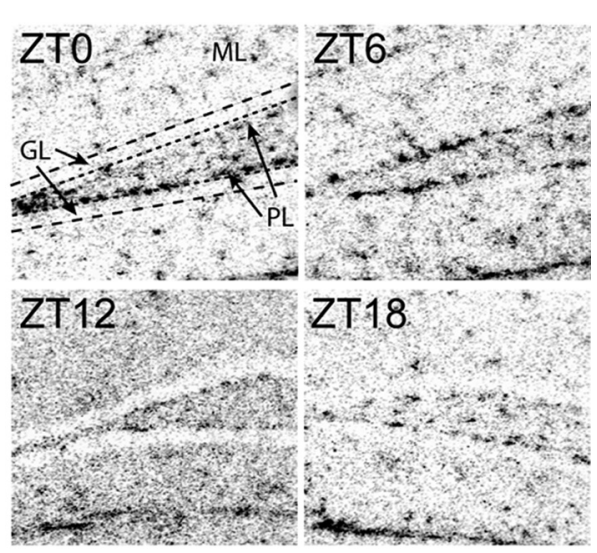

$\mathrm{B}$

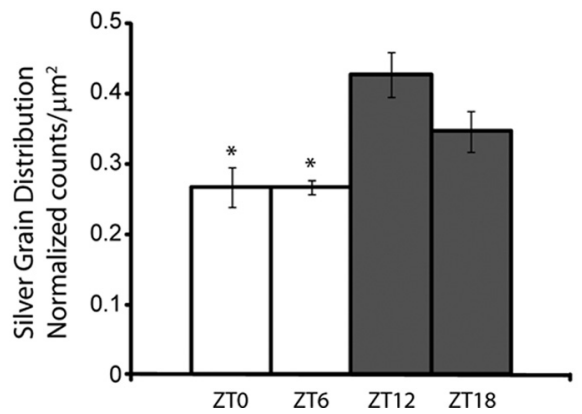

Figure 3. Fabp7 mRNA distribution cycles diurnally in hippocampus. $\boldsymbol{A}$, Representative coronal in situ hybridization hippocampal tissue sections probed for Fabp7 mRNA, subjected to emulsion autoradiography and dark-field microscopy at four diurnal time points. Note the dispersion in signal observed at ZT12 compared with the other time points. ML, molecular layer; $\mathrm{GL}$, granular layer (between large and small dashed lines), PL, precursor layer (on edge of small dashed line). $\boldsymbol{B}$, Analysis of relative mRNA distribution over the light/dark cycle in the molecular layers of hippocampus reveals a significant time-of-day effect. One-way ANOVA, $p=0.0156$; ${ }^{*} p<0.05$ ZT12 vs ZT0 and 6, post hoc Tukey. Each value represents the mean \pm SEM. Light bars, light period; dark bars, dark period. Emulsion image contrast was inverted for clarity.

Table 1. Phylogenetic conservation of CPEs in the 3' UTR of Fabp7 mRNA

\begin{tabular}{cccc}
\hline & Sequence & Nucleotide number & Location \\
\hline CPE-1 & & & \\
DR 590 & UGUUUUUUAAUUAU & $603=56 \mathrm{nt}$ & Upstream of hex \\
GG 630 & UUUUUUUUAACAGU & $643=57 \mathrm{nt}$ & Upstream of hex \\
MM 691 & UACUUUUUAUAGAA & $704=56 \mathrm{nt}$ & Upstream of hex \\
RN 679 & UUUUUUUUAUAAA & $692=57 \mathrm{nt}$ & Upstream of hex \\
SS 715 & UUUUUUUUAAAUAU & $728=59 \mathrm{nt}$ & Upstream of hex \\
HS 919 & UUUUUUUUAUAAC & $932=57 \mathrm{nt}$ & Upstream of hex \\
CPE-2+ & & & \\
DR 603 & UUAUUUUUAUUUGU & $616=43 \mathrm{nt}$ & Upstream of hex \\
GG 537 & UUUUUUUUAAGAAA & $550=153 \mathrm{nt}$ & Upstream of hex \\
MM 680 & AUAAUUUUAACAAU & $693=66 \mathrm{nt}$ & Upstream of hex \\
MM 669 & UUUUUUUUAAAUAA & $682=77 \mathrm{nt}$ & Upstream of hex \\
RN 655 & UUUUUUUUAAUAAC & $668=81 \mathrm{nt}$ & Upstream of hex \\
SS 621 & CUUGUUUUAAAAAC & $634=152 \mathrm{nt}$ & Upstream of hex \\
HS 940 & UACAUUUUUAUAAU & $953=35 \mathrm{nt}$ & Upstream of hex \\
HS 879 & GUACUUUUAUAAUU & $892=97 \mathrm{nt}$ & Upstream of hex \\
\hline
\end{tabular}

CPE-1 and (PE-2+ are shown within proximity to their nucleotide number and location relative to the polyadenylation hexanucleotide (hex) sequence. DR, Danio rerio; GG, Gallus gallus; $M$ M, Mus musculus; $\mathrm{RN}$, Rattus norvigicus; $\mathrm{SS}$, Sus scrofa; $\mathrm{HS}$, Homo sapiens.

served in all species examined (Table 1). The relative distance and loci of the CPEs from the hexanuculeotide (AAUAAA) are also conserved in multiple species (Table 1), suggesting functional regulatory mechanisms underlying Fabp7 mRNA translational control conserved across species.
A
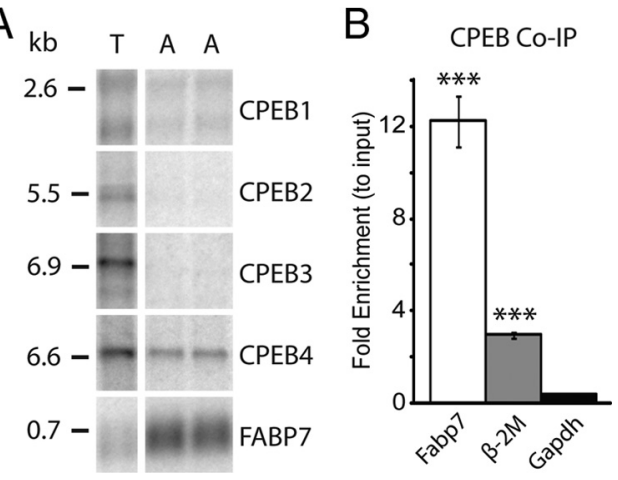

Figure 4. CPEB1 binds Fabp7 mRNA in astrocytes. $A$, Northern blot analysis of various CPEBs reveals expression from whole mouse brain total RNA (T) or CPEB1 and CPEB4 from cultured primary astrocyte RNA (A). Enrichment of Fabp7 mRNA in astrocytes is shown as a positive control. $\boldsymbol{B}$, Coimmunoprecipitation of Fabp7 mRNA with CPEB1 from astrocyte lysate. Enrichment of Fabp7 and the positive control $\beta-2$ microglobulin mRNA (IP vs input) compared with GAPDH mRNA (IP vs input) ( $t$ test, $\left.{ }^{* * *} p<0.001\right)$. Fabp7 vs GAPDH; $\beta$-2M vs GAPDH. Data are mean \pm SEM. $N=3$ /group).

CPEB machinery exists in astrocytes and binds Fabp7 mRNA Four CPEB proteins have been characterized in adult mammalian brain (Theis et al., 2003), and CPEB1 was previously shown to be expressed in astrocytes (Jones et al., 2008). To confirm the presence of CPEB1, and determine whether the other CPEBs exist in astrocytes, Northern blot analysis of mRNA from cultured murine primary astrocytes was performed. The presence of CPEB1 and CPEB4, but not CPEB2 or CPEB3 mRNA, was identified in astrocyte culture homogenates (Fig. $4 A$ ). All CPEBs were observed in total RNA from whole brain (Fig. 4A), confirming previous studies (Theis et al., 2003; Rouhana et al., 2005).

Given murine Fabp7 mRNA contains CPEs, we performed coimmunoprecipitation experiments on lysate from mouse primary astrocyte culture to assess whether CPEB1 binds to Fabp7 mRNA. This method selectively restricts interactions of CPEB protein with Fabp7 mRNA expressed specifically in astrocytes, eliminating the possibility for false-positive interactions from whole-brain lysate. There was a $\sim 12$-fold enrichment of Fabp7 mRNA in the eluate of anti-CPEB1-conjugated protein-A beads compared with input (Fig. 4B). Previously the CPE-containing $\beta 2$ microglobulin mRNA was identified in a microarray screen search for CPEB1-bound mRNAs from mammalian brain $(\mathrm{Du}$ and Richter, 2005). $\beta 2$ microglobulin is also present in astrocytes (Diedrich et al., 1993; Vanguri, 1995), and therefore we used it as a positive control for a CPEB-interacting mRNA. QRT-PCR analysis of CPEB1 co-IP showed a $\sim 3$-fold enrichment of $\beta 2$ microglobulin mRNA compared with input, confirming previous findings of binding to CPEB1 (Du and Richter, 2005). A statistically significant elevation in Fabp7 mRNA compared with $\beta 2$ microglobulin mRNA co-IP was observed ( $t$ test, $p<0.01$ ), suggesting that Fabp7 mRNA binds to CPEB with greater affinity.

\section{CPE function}

CPE mediates cytoplasmic regulation of Fabp7 mRNA translation Since Fabp7 mRNA binds CPEB1 in cultured astrocytes (Fig. 4B), we were interested in determining whether the CPEs are functional. To do so, we tested whether the Fabp7 mRNA 3'UTR would control translation during Xenopus oocyte maturation. Legitimate CPEs from neuronal mRNAs are commonly active in this assay, enhancing translation and promoting polyadenylation during oocyte maturation (Wu et al., 1998; Kim and Richter, 2008; Novoa et al., 2010; Igea and Mendez, 2010). 


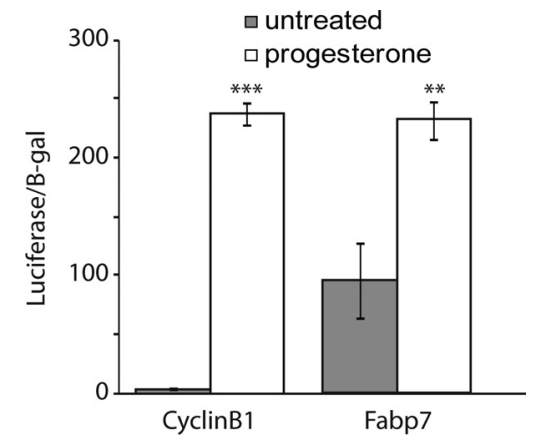

Figure 5. Translational stimulation by the Fabp73'UTR. Luciferase activity of progesteronestimulated Xenopus 0ocytes shows a statistically significant increase in translation for mouse Fabp7 $3^{\prime}$ UTR ( $t$ test, ${ }^{* *} p<0.01$ ). Cyclin B1 3' UTR (positive control) shows a typical activation response following progesterone stimulation ( $t$ test, $\left.{ }^{* * *} p<0.001\right)$. Data are mean $\pm S E M$, normalized to coinjected $\beta$-gal for control ( $N=3$ /group).

The murine Fabp7 3'UTR was subcloned downstream of the luciferase open-reading frame, and the resulting mRNA injected into Xenopus oocytes, half of which were then induced to mature using progesterone (Rouhana and Wickens, 2007). A $\beta$-galactosidase reporter without the Fabp7 3'UTR was coinjected for normalization. A 2.4-fold induction of luciferase activity was observed following progesterone stimulation, demonstrating that translational stimulation elements operate on the Fabp7 3' UTR (Fig. 5). An mRNA carrying the cyclin B1 3'UTR served as a positive control, and exhibited translational repression in resting oocytes and translational activation after maturation, as expected (de Moor and Richter, 1999; Barkoff et al., 2000).

A time course analysis showed a temporal window of luciferase/Fabp7 mRNA 3'UTR translation peaking at $7 \mathrm{~h}$ following progesterone stimulation (Fig. 6). Mutations in either the CPEs or the cleavage and polyadenylation specificity hexanucleotide, both of which are required for cytoplasmic polyadenylation (Fox et al., 1989), blocked the translational stimulation mediated by the Fabp7 3'UTR (Fig. 6). Mutations in the CPEs release repression of translation, leading to an increase in luciferase activity in unstimulated oocytes compared with wild type. These observations are similar to other validated CPEcontaining 3'UTRs using this assay, such as in the 3'UTR of CPEB4 mRNA (Igea and Mendez, 2010). We conclude that the Fabp7 3'UTR possesses functional CPEs.

Fabp7 mRNA poly (A) tail is diurnally regulated in mouse brain CPE-containing mRNAs are known to regulate polyadenylation and subsequent translation (Wu et al., 1998; Wells et al., 2001; Du and Richter, 2005; Igea and Mendez, 2010). Since Fabp7 mRNA binds to CPEB1, is translationally regulated by existing CPEs in its $3^{\prime} \mathrm{UTR}$, and trafficked in astrocytes in a time-of-daydependent manner, a corresponding diurnal change in the poly(A) tail can be predicted. To determine whether Fabp7 mRNA has a corresponding change in polyadenylation, we examined the pattern of mRNA length over the light/dark cycle. We previously reported that the abundance of Fabp7 mRNA varies with time of day in multiple brain regions (Gerstner et al., 2006, 2008). Reanalysis of that data revealed that the lengths of the Fabp7 mRNA, and not merely its abundance, vary in each of these regions of the brain. This is a specific effect, since Fabp 5 mRNA length (data not shown), another Fabp of similar size expressed in CNS glia (Veerkamp and Zimmerman, 2001), does not vary. To confirm that this change in Fabp7-banding pattern was a result of alterations in poly(A) tail length, we used RNase $\mathrm{H}$ analysis. The
RNase $\mathrm{H}$ enzyme hydrolizes phosphodiester bonds of RNA hybridized to DNA, and is used for determining polyadenylation (Goodwin and Rottman, 1992). Using an oligo-dT DNA primer and hybridizing it to total brain poly(A) RNA, a consistent mobility of digested Fabp7 mRNA products were observed following digestion in the presence of the RNase H enzyme at both ZT12 and 24 time points in whole-brain homogenates examined by Northern blotting (data not shown). Closer examination of RNase $\mathrm{H}$ digested poly(A) mRNA products using oligo-dT at multiple time points confirmed a single predicted Fabp7 mRNA band at $762 \mathrm{bp}$ (Fig. 7A). Synchronization of this banding pattern was observed in multiple regions throughout murine brain (Gerstner et al., 2006, 2008), including regions involved in circadian rhythms (suprachiasmatic nucleus) and sleep/wake regulation (ventrolateral preoptic nucleus, tuberomammalary nucleus, lateral hypothalamus, locus ceruleus, pons) (Saper et al., 2010). A comparison of the changes in mRNA level and polyadenylation shows an increased length in poly(A) tail when the Fabp7 mRNA is low, during the dark period, at ZT18 (Fig. 7B).

\section{Discussion}

The results presented here are the first to show that circadian changes in polyadenylation occur in a non-neuronal mRNA in mammalian brain, and that a diurnally controlled mRNA is posttranscriptionally regulated by CPEB-mediated cytoplasmic polyadenylation. Fabp7 mRNA polyadenylation is mediated, at least in part, through cis-regulatory elements in the Fabp7 mRNA's 3'UTR that are phylogenetically conserved. Further, CPEs in the Fabp7 3'UTR are necessary for repression of translation in the Xenopus oocyte maturation assay and Fabp7 transcript is bound by $\mathrm{CPEB} 1$ in mouse astrocytes. These data provide a novel mechanism for coordinated CPEB-mediated translational processing of mRNA in astrocytes over the circadian cycle in mammalian brain.

An aging-dependent decline in Fabp7 protein in synaptoneurosomal fractions of mouse brain was previously observed (Pu et al., 1999). We confirmed that the Fabp7 was present in the fine perisynaptic processes of astrocytes using electron microscopy, and observed a time-of-day-dependent alteration in Fabp7 mRNA localization in synaptoneurosomal fractions. Exactly whether an aging-dependent decrease in Fabp7 protein in synaptoneurosomal fractions is due to an overall decrease in Fabp7 levels, or some deficit in subcellular localization and/or polyadenylation mechanisms remains to be determined. However, since Fabp7 binds the $\omega$ - 3 polyunsaturated fatty-acid, docosahexaenoic acid (DHA), to high affinity (Xu et al., 1996) and DHA has been implicated in Alzheimer's disease and cognitive function (Morley and Banks, 2010), it is possible that alterations in Fabp7 processing or targeting contributes to age-related cognitive decline. This is an intriguing possibility since amyloid-precursor proteins, which are believed to contribute to $\mathrm{Alz}$ heimer's disease etiology (Tanzi and Bertram, 2005; Haass and Selkoe, 2007), have been shown to act as membrane anchors for the cytoplasmic translational activity of CPEB (Cao et al., 2005). It is possible that misregulation of CPEB-mediated Fabp7 mRNA posttranscriptional events could contribute to an aging-dependent decline in cognitive processing and/or neurodegenerative disease related to fatty-acid signaling (Di Paolo and Kim, 2011).

CPEBs are mRNA-binding proteins involved in subcellular trafficking and local translation of targeted mRNAs at synapses (Huang et al., 2003). We confirmed that CPEB1 also exists in astrocytes as described previously (Jones et al., 2008), and characterized functional CPE-sites in the Fabp7 3'UTR. However, the physiological signals that direct Fabp7 mRNA trafficking and polyadenylation remain unknown. Since Fabp7 has been shown 
to regulate cellular outgrowth (Feng et al., 1994; Arai et al., 2005) and motility (Mita et al., 2010), CPE-mediated polyadenylation and targeting of Fabp7 may be involved in regulating astrocytic process extension in plasticity-related contexts. It is not yet known, however, whether changes in neuronal activity and/or synaptic plasticity affect trafficking and polyadenylation of Fabp7 mRNA, leading to morphological changes in astrocytic processes.

Our results show that Fabp7 mRNA undergoes longer poly(A) extension during a time window when the base levels of mRNA are lower. Interestingly, the shortest poly(A) tail was observed at ZT12, the time point of greatest mRNA dispersal, suggesting either dormant or degraded Fabp7 mRNA is directed away from cell bodies at the light-todark transition. Dramatic increases in levels of Fabp7 heteronuclear RNA transcripts were previously observed at the dark-tolight transition (Gerstner et al., 2008), suggesting a major transcriptional event and reflected by the concentrated somatic localization of silver grain density observed in astrocytes during the light period (Fig. 3A). This suggests that increases in Fabp7 poly(A) tail length at times of lower mRNA levels are likely not derived from nuclear transcriptional events per se, but instead are controlled post-transcriptionally through mechanisms involving CPEB-mediated translational activation (see Fig. 8). Protein kinase activity is thought to direct phosphorylation of CPEB and to regulate polyadenylation of target transcripts (Richter, 2007). One prediction is that similar kinase activation of CPEB exists in astrocytes, gated by time-of-day alterations in neuronal activity, metabolism, or behavioral state. This might be expected at light/dark transition times, when animals switch between dormant and active states, where sleep/wake neurophysiology could signal changes in Fabp7 mRNA perisynaptic localization, polyadenylation, and subsequent translation. Therefore, one prediction would be that activity state at specific times of day contributes to Fabp7 mRNA trafficking, polyadenylation, and protein accumulation in perisynaptic astroglial processes. Whether CPEB activation fits this model (Fig. 8) or state-dependent signaling pathways and kinases mediate this process remains to be determined.

The oscillation in trafficking observed within the hippocampus introduces an additional level of complexity for Fabp7 posttranscriptional regulation in astrocytes. Since CPEB is thought to stimulate trafficking and translation of plasticity-related mRNAs, such as $\alpha$ CaMKII, to recently activated synapses (Wu et al., 1998; Bramham and Wells, 2007; Richter, 2007), it is tempting to speculate that the diurnal trafficking observed for Fabp7 mRNA may be mediated by CPEB through astrocytic responses to neuronal ACACACAC- $3^{\prime}$

B
A ACUGGUCACUAAUUAUAAGUUUGUCUUCGGUGUGGAGGUAGAAAAUUAUAAUUCUAAGAUGUGUUACU CCAAGCAAUUCAUGGGAUUUUGAUAUGCAAAUUUACUGUUUUCCAUUUUUUUUUAAAUAAUUUUACAAU ACUUUUUUUUAGAAAUGGGAAUAUACUUAUGACUUUCUUUGGAAUGCAAACCAAAUUGAAAUAAAAAAU

\section{Fabp7 mRNA}

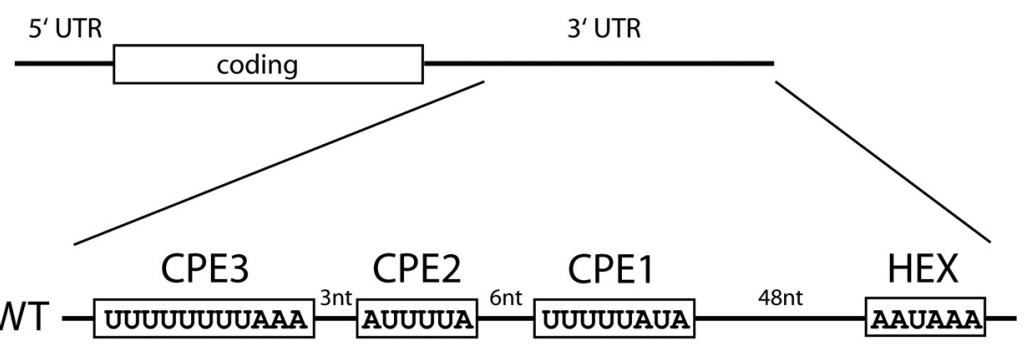

3xCPEmt - UUggUUCCAAA $\frac{3 \mathrm{nt}}{\operatorname{cog}} \operatorname{ccUAA} \frac{6 \mathrm{nt}}{\mathrm{UUggUACC}}$ 48nt AAUAAA-

HEXmt - UUUUUUUUAAA 3 AUUUUA ${ }^{6 n t}$ UUUUUAUA 48nt
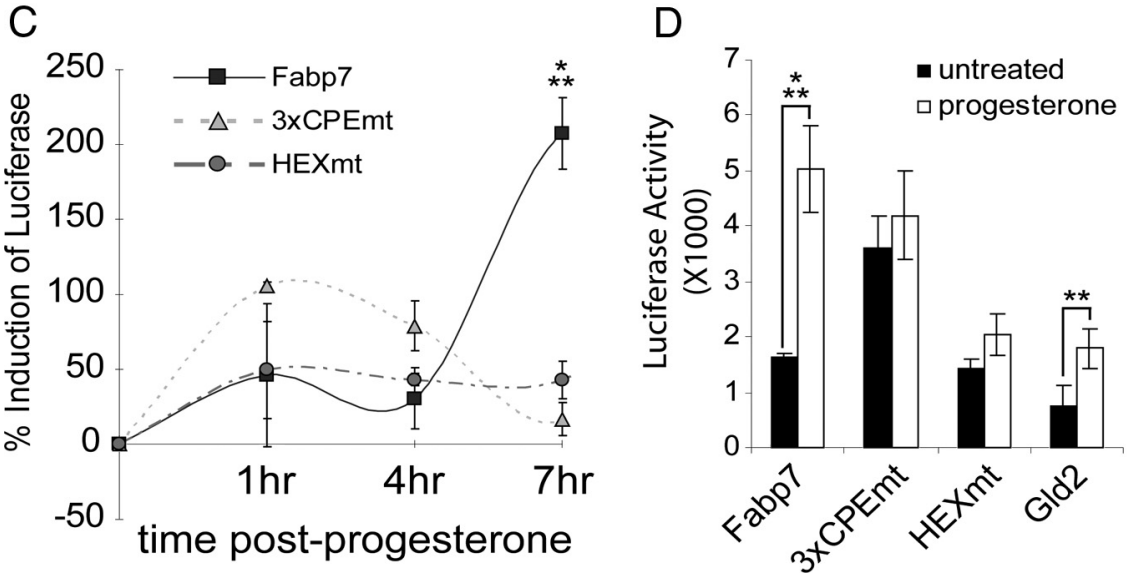

Figure 6. Fabp7 mRNA translation is regulated by CPEs. $A$, The $3^{\prime} U$ UT sequence of the murine Fabp7 $m$ RNA is depicted with the CPEs in bold, and the hexanucleotide underlined and in bold. $\boldsymbol{B}$, Schematic diagram of the Fabp7 mRNA structure, with the sequence and relative locations of wild type (WT), 3XCPE mutant (3XCPEmt), and hexanucleotide mutant (HEXmt). Mutated nucleotides are shown in lower case. C, Firefly luciferase ORF fused to $3^{\prime}$ UTR of Fabp7 3'UTR wild type (Fabp7); Fabp7 3'UTR 3XCPEmt; and Fabp7 3'UTR HEXmt was injected into oocytes, and the percentage of induced luciferase activity is shown at indicated time points following progesterone stimulation (normalized to baseline unstimulated oocyte controls). Two-way ANOVA; effect of genotype with time $p<0.001$; post hoc Bonferroni Fabp7 vs $3 X$ CPEmt and vs HEXmt at $7 \mathrm{~h},{ }^{* * *} p<0.001$. Data are mean \pm SEM $(N=4)$. D, Firefly luciferase ORF fused to 3'UTR of wild-type GId2 (positive control), Fabp7, 3XCPEmt, and HEXmt were injected into 00 cytes and incubated in the absence (repression) or presence (activation) of progesterone. Luciferase activities were determined after $7 \mathrm{~h}$. One-way ANOVA, $p<0.001$; post hoc Bonferroni Fabp7, ${ }^{* * *} p<0.001$, and Gld2, ${ }^{* *} p<0.01$, untreated to progesterone treatment. Data are mean $\pm \operatorname{SEM}(N=4)$.

activity. Fabp7 mRNA increases following neuronal activity within hippocampus following kainate stimulation (Owada et al., 1996). While mechanisms underlying post-transcriptional processing of clock and clock-controlled genes are beginning to be understood (Kojima et al., 2011), to the best of our knowledge, a role for CPEB in the regulation of post-transcriptional processing of diurnally regulated mRNA has not yet been examined. Our data presented here indicate that astrocytic Fabp7 transcription and subsequent trafficking to perisynaptic process compartments oscillate based on time of day through a putative CPEBmediated mechanism (Fig. 8). 

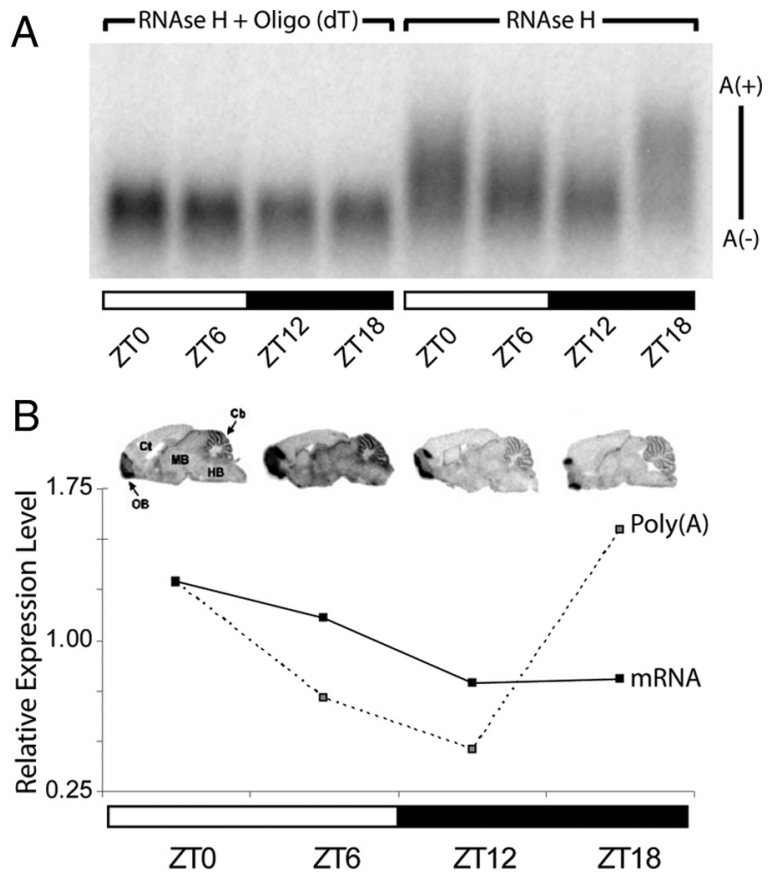

Figure 7. Diurnal changes in Fabp7 mRNA polyadenylation. $\boldsymbol{A}$, Northern blot analysis of RNase $\mathrm{H}$ digestion of Fabp7 mRNA in the presence of Oligo- $\mathrm{dT}$ shows a single band at various time points over the light/dark cycle. RNase $H$ in the absence of Oligo-dT reveals the time-of-day regulation of Fabp7 mRNA polyadenylation, which is lowest near the light-to-dark transition at ZT12. B, In situ hybridization of Fabp7 mRNA on sagittal sections of mouse brain over the light/dark cycle (top) show broad changes in expression, with lower levels during the dark period. Relative changes in Fabp7 mRNA and poly $(A)$ tail are observed out of phase, with mRNA levels highest early in the light period, and poly $(A)$ tail longest toward the end of the dark period. $\mathrm{OB}$, olfactory bulb; $\mathrm{Ct}$, cortex; $\mathrm{MB}$, midbrain; $\mathrm{HB}$, hind-brain; $\mathrm{Cb}$, cerebellum. Light bars, light period; dark bars, dark period.

In addition to the presynaptic and postsynaptic neuronal terminals, an astroglial process, which surrounds the synapse, is an active participant in neural transmission and defines a unique compartment called the tripartite synapse (Halassa et al., 2007, 2009 b). Astrocytes, through these perisynaptic processes, are believed to both sequester neurotransmitters and release gliotransmitters and factors to modulate synaptic activity (Halassa and Haydon, 2010). Previously, the glial fibrillary acidic protein (GFAP) mRNA was identified in SN fractions (Rao and Steward, 1993), molecular evidence for the presence of astroglial processes of the tripartite synapse. Glial cells also respond to neuronal activity. For example, an increase in GFAP expression has been observed in rat hippocampus following electrically induced seizures (Steward et al., 1991). A fivefold increase of GFAP mRNA was also observed at $24 \mathrm{~h}$ following seizure stimulation before returning to baseline levels 4 d later (Torre et al., 1993). Interestingly, Fabp7 mRNA has a similar hippocampal expression profile following kainate injection, where it is elevated $24 \mathrm{~h}$ later, reaching peak expression after $48 \mathrm{~h}$ (Owada et al., 1996), a time that corresponds to peak GFAP protein expression (Torre et al., 1993). Since Fabp7 mRNA is enriched in dendritic layers of hippocampus (Zhong et al., 2006), and present in synaptoneurosomes (Pu et al., 1999) (Figs. 1, 2), these data suggest that Fabp7targeted perisynaptic translocation and subsequent translation within astrocytes may have some function related to changes in neuronal activation or synaptic homeostasis. We did not observe time-of-day-dependent changes in polyadenylation of the Fabp7 mRNA in primary astrocyte culture (data not shown), suggesting that the presence of nonastroglial factors are responsible for

\section{Diurnal Fabp7 post-transcriptional processing}
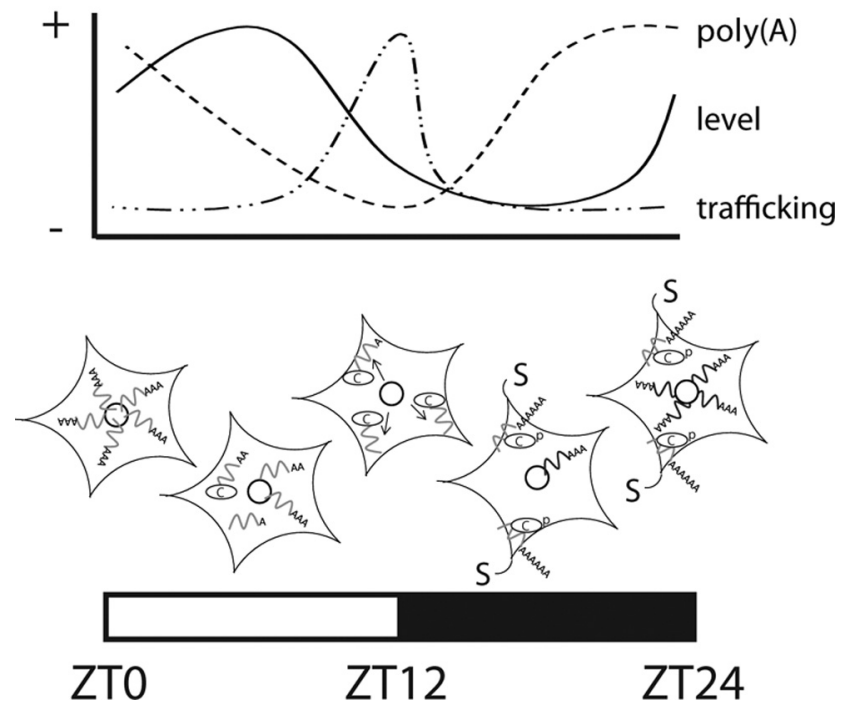

Figure 8. Model for time-of-day regulation of Fabp7 mRNA processing in astrocytes. Top, Summary of findings showing diurnal changes in levels of Fabp7 mRNA, poly $(A)$ tail length, and trafficking. Bottom, Peak in Fabp7 transcription occurs near dawn, with moderate polyadenylation signal and a somatic distribution, reflecting recently transcribed RNA in the nucleus. A gradual decline in transcription and polyadenylation signal continues over the light phase. Lowest levels of poly $(A)$ are observed at dusk, at a time of greatest mRNA dispersal. Targeting of mRNA is initiated in the dark phase to perisynaptic processes $(S)$ and corresponding induction of polyadenylation via CPEB (C). CPEB translational activation via phosphorylation ( $p$ ) may occur during this period. Localization at $S$ is higher during this time. Fabp7 mRNA returns to higher levels the following morning, following new transcription. Light bars, light period; dark bars, dark period.

changes in Fabp7 post-transcriptional processing. Future work will determine whether neuronal activity is required for the observed effects on Fabp7 mRNA regulation.

Since we show a time-of-day change in Fabp7 mRNA localization to synapses and subcellular trafficking in hippocampus, another intriguing possibility is that Fabp7 function at synapses may be related to time-of-day-dependent changes observed in synaptic plasticity and memory formation (Gerstner et al., 2009; Gerstner and Yin, 2010). DHA is an $\omega$-3 polyunsaturated fattyacid known to bind Fabp7 to high affinity (Xu et al., 1996), is abundant in the synaptic compartment (Breckenridge et al., 1972; Salem et al., 2001), regulates synaptic plasticity (Young et al., 1998; Itokazu et al., 2000; Fujita et al., 2001; Mirnikjoo et al., 2001), and influences learning and memory behavior (Moriguchi et al., 2000; Moriguchi and Salem, 2003; Fedorova et al., 2007, 2009). DHA-stimulated NMDA-receptor-dependent current is blocked in neurons derived from Fabp7 KO mice (Owada et al., 2006), suggesting that Fabp7 localization in tripartite synapses influences neurophysiological function. Such Fabp7-dependent modulation of synaptic efficacy may in turn regulate memory processes. This is evident from observations of significant alterations in later periods of memory behavior in a passive avoidanceconditioning task in Fabp7 $\mathrm{KO}$ mice compared with wild-type mice (Owada et al., 2006). Recently we have shown that Fabp7 overexpression in Drosophila leads to changes in daytime sleep behavior and increases in memory consolidation (Gerstner et al., 2011a,b). These data implicate a functional role for subcellular localization of Fabp7 in mediating neural plasticity and time-ofday-dependent changes in complex behavior. 
In conclusion, we provide the first evidence of circadian changes in polyadenylation for the astrocyte Fabp7 mRNA in mammalian brain. We characterize poly(A) tail processing and translational regulation of Fabp7 mRNA through CPE-sites in its 3'UTR, and describe an interaction with CPEB1 in astrocytes. We show the time-of-day-dependent trafficking of Fabp7 mRNA in the mouse hippocampus. We also provide biochemical and ultrastructural evidence of Fabp7 protein in perisynaptic processes of the tripartite synapse, where mRNA abundance changes logarithmically based on time of day. These changes are novel for known circadian genes and implicate Fabp7 post-transcriptional processing in the temporal regulation of the astrocytic component of the tripartite synapse.

\section{References}

Abarca C, Albrecht U, Spanagel R (2002) Cocaine sensitization and reward are under the influence of circadian genes and rhythm. Proc Natl Acad Sci U S A 99:9026-9030.

Andretic R, Chaney S, Hirsh J (1999) Requirement of circadian genes for cocaine sensitization in Drosophila. Science 285:1066-1068.

Arai Y, Funatsu N, Numayama-Tsuruta K, Nomura T, Nakamura S, Osumi N (2005) Role of Fabp7, a downstream gene of Pax6, in the maintenance of neuroepithelial cells during early embryonic development of the rat cortex. J Neurosci 25:9752-9761.

Ballantyne S, Daniel DL Jr, Wickens M (1997) A dependent pathway of cytoplasmic polyadenylation reactions linked to cell cycle control by c-mos and CDK1 activation. Mol Biol Cell 8:1633-1648.

Barkoff AF, Dickson KS, Gray NK, Wickens M (2000) Translational control of cyclin B1 mRNA during meiotic maturation: coordinated repression and cytoplasmic polyadenylation. Dev Biol 220:97-109.

Bracchi-Ricard V, Brambilla R, Levenson J, Hu WH, Bramwell A, Sweatt JD, Green EJ, Bethea JR (2008) Astroglial nuclear factor-kappaB regulates learning and memory and synaptic plasticity in female mice. J Neurochem 104:611-623.

Bramham CR, Wells DG (2007) Dendritic mRNA: transport, translation and function. Nat Rev Neurosci 8:776-789.

Breckenridge WC, Gombos G, Morgan IG (1972) The lipid composition of adult rat brain synaptosomal plasma membranes. Biochim Biophys Acta 266:695-707.

Brown V, Jin P, Ceman S, Darnell JC, O'Donnell WT, Tenenbaum SA, Jin X, Feng Y, Wilkinson KD, Keene JD, Darnell RB, Warren ST (2001) Microarray identification of FMRP-associated brain mRNAs and altered mRNA translational profiles in fragile X syndrome. Cell 107:477-487.

Cao Q, Huang YS, Kan MC, Richter JD (2005) Amyloid precursor proteins anchor CPEB to membranes and promote polyadenylation-induced translation. Mol Cell Biol 25:10930-10939.

Chaudhury D, Colwell CS (2002) Circadian modulation of learning and memory in fear-conditioned mice. Behav Brain Res 133:95-108.

Chaudhury D, Wang LM, Colwell CS (2005) Circadian regulation of hippocampal long-term potentiation. J Biol Rhythms 20:225-236.

de Moor CH, Richter JD (1999) Cytoplasmic polyadenylation elements mediate masking and unmasking of cyclin B1 mRNA. EMBO J 18:2294-2303.

Diedrich JF, Carp RI, Haase AT (1993) Increased expression of heat shock protein, transferrin, and beta 2 -microglobulin in astrocytes during scrapie. Microb Pathog 15:1-6.

Di Paolo G, Kim TW (2011) Linking lipids to Alzheimer's disease: cholesterol and beyond. Nat Rev Neurosci 12:284-296.

Du L, Richter JD (2005) Activity-dependent polyadenylation in neurons. RNA 11:1340-1347.

Dudley CA, Erbel-Sieler C, Estill SJ, Reick M, Franken P, Pitts S, McKnight SL (2003) Altered patterns of sleep and behavioral adaptability in NPAS2deficient mice. Science 301:379-383.

Eckel-Mahan KL, Storm DR (2009) Circadian rhythms and memory: not so simple as cogs and gears. EMBO Rep 10:584-591.

Fedorova I, Hussein N, Di Martino C, Moriguchi T, Hoshiba J, Majchrzak S, Salem N Jr (2007) An n-3 fatty acid deficient diet affects mouse spatial learning in the Barnes circular maze. Prostaglandins Leukot Essent Fatty Acids 77:269-277.

Fedorova I, Hussein N, Baumann MH, Di Martino C, Salem N Jr (2009) An n-3 fatty acid deficiency impairs rat spatial learning in the barnes maze. Behav Neurosci 123:196-205.

Feillet CA, Ripperger JA, Magnone MC, Dulloo A, Albrecht U, Challet E (2006) Lack of food anticipation in Per2 mutant mice. Curr Biol 16:2016-2022.

Feng L, Hatten ME, Heintz N (1994) Brain lipid-binding protein (BLBP): a novel signaling system in the developing mammalian CNS. Neuron 12:895-908.

Florian C, Vecsey CG, Halassa MM, Haydon PG, Abel T (2011) Astrocytederived adenosine and A1 receptor activity contribute to sleep lossinduced deficits in hippocampal synaptic plasticity and memory in mice. J Neurosci 31:6956-6962.

Fox CA, Sheets MD, Wickens MP (1989) Poly(A) addition during maturation of frog oocytes: Distinct nuclear and cytoplasmic activities and regulation by the sequence UUUUUAU. Genes Dev 3:2151-2162.

Fujita S, Ikegaya Y, Nishikawa M, Nishiyama N, Matsuki N (2001) Docosahexaenoic acid improves long-term potentiation attenuated by phospholipase $\mathrm{A}(2)$ inhibitor in rat hippocampal slices. $\mathrm{Br} \mathrm{J}$ Pharmacol 132:1417-1422.

Fuller PM, Gooley JJ, Saper CB (2006) Neurobiology of the sleep-wake cycle: sleep architecture, circadian regulation, and regulatory feedback. J Biol Rhythms 21:482-493.

Garcia JA, Zhang D, Estill SJ, Michnoff C, Rutter J, Reick M, Scott K, DiazArrastia R, McKnight SL (2000) Impaired cued and contextual memory in NPAS2-deficient mice. Science 288:2226-2230.

Gerstner JR, Landry CF (2007) The zinc-binding protein chordc1 undergoes complex diurnal changes in mRNA expression during mouse brain development. Neurochem Res 32:241-250.

Gerstner JR, Lyons LC, Wright KP Jr, Loh DH, Rawashdeh O, Eckel-Mahan KL, Roman GW (2009) Cycling behavior and memory formation. J Neurosci 29:12824-12830.

Gerstner JR, Yin JC (2010) Circadian rhythms and memory formation. Nat Rev Neurosci 11:577-588.

Gerstner JR, Vander Heyden WM, Lavaute TM, Landry CF (2006) Profiles of novel diurnally regulated genes in mouse hypothalamus: expression analysis of the cysteine and histidine-rich domain-containing, zincbinding protein 1 , the fatty acid-binding protein 7 and the GTPase, raslike family member 11b. Neuroscience 139:1435-1448.

Gerstner JR, Bremer QZ, Vander Heyden WM, Lavaute TM, Yin JC, Landry CF (2008) Brain fatty acid binding protein (Fabp7) is diurnally regulated in astrocytes and hippocampal granule cell precursors in adult rodent brain. PLoS One 3:e1631.

Gerstner JR, Vanderheyden WM, Shaw PJ, Landry CF, Yin JC (2011a) Fattyacid binding proteins modulate sleep and enhance long-term memory consolidation in Drosophila. PLoS One 6:e15890.

Gerstner JR, Vanderheyden WM, Shaw PJ, Landry CF, Yin JC (2011b) Cytoplasmic to nuclear localization of fatty-acid binding protein correlates with specific forms of long-term memory in Drosophila. Commun Integr Biol 4:623-626.

Gibbs ME, Hertz L (2008) Inhibition of astrocytic energy metabolism by D-lactate exposure impairs memory. Neurochem Int 52:1012-1018.

Gibbs ME, Anderson DG, Hertz L (2006) Inhibition of glycogenolysis in astrocytes interrupts memory consolidation in young chickens. Glia 54:214-222.

Goodwin EC, Rottman FM (1992) The use of RNase H and poly(A) junction oligonucleotides in the analysis of in vitro polyadenylation reaction products. Nucleic Acids Res 20:916.

Gray NK, Coller JM, Dickson KS, Wickens M (2000) Multiple portions of poly(A)-binding protein stimulate translation in vivo. EMBO J 19:4723-4733.

Haass C, Selkoe DJ (2007) Soluble protein oligomers in neurodegeneration: Lessons from the Alzheimer's amyloid beta-peptide. Nat Rev Mol Cell Biol 8:101-112.

Halassa MM, Haydon PG (2010) Integrated brain circuits: astrocytic networks modulate neuronal activity and behavior. Annu Rev Physiol 72:335-355

Halassa MM, Fellin T, Haydon PG (2007) The tripartite synapse: roles for gliotransmission in health and disease. Trends Mol Med 13:54-63.

Halassa MM, Florian C, Fellin T, Munoz JR, Lee SY, Abel T, Haydon PG, Frank MG (2009a) Astrocytic modulation of sleep homeostasis and cognitive consequences of sleep loss. Neuron 61:213-219.

Halassa MM, Fellin T, Haydon PG (2009b) Tripartite synapses: roles for 
astrocytic purines in the control of synaptic physiology and behavior. Neuropharmacology 57:343-346.

Harris KM, Teyler TJ (1983) Age differences in a circadian influence on hippocampal LTP. Brain Res 261:69-73.

Herzog ED (2007) Neurons and networks in daily rhythms. Nat Rev Neurosci 8:790-802.

Huang YS, Carson JH, Barbarese E, Richter JD (2003) Facilitation of dendritic mRNA transport by CPEB. Genes Dev 17:638-653.

Igea A, Méndez R (2010) Meiosis requires a translational positive loop where CPEB1 ensues its replacement by CPEB4. EMBO J 29:2182-2193.

Itokazu N, Ikegaya Y, Nishikawa M, Matsuki N (2000) Bidirectional actions of docosahexaenoic acid on hippocampal neurotransmissions in vivo. Brain Res 862:211-216.

Jones KJ, Korb E, Kundel MA, Kochanek AR, Kabraji S, McEvoy M, Shin CY, Wells DG (2008) CPEB1 regulates beta-catenin mRNA translation and cell migration in astrocytes. Glia 56:1401-1413.

Kim JH, Richter JD (2008) Measuring CPEB-mediated cytoplasmic polyadenylation-deadenylation in xenopus laevis oocytes and egg extracts. Methods Enzymol 448:119-138.

Kojima S, Shingle DL, Green CB (2011) Post-transcriptional control of circadian rhythms. J Cell Sci 124:311-320.

Kondratova AA, Dubrovsky YV, Antoch MP, Kondratov RV (2010) Circadian clock proteins control adaptation to novel environment and memory formation. Aging 2:285-297.

Li X, Sankrithi N, Davis FC (2002) Transforming growth factor-alpha is expressed in astrocytes of the suprachiasmatic nucleus in hamster: Role of glial cells in circadian clocks. NeuroReport 13:2143-2147.

Lyons LC, Roman G (2009) Circadian modulation of short-term memory in Drosophila. Learn Mem 16:19-27.

Lyons LC, Rawashdeh O, Katzoff A, Susswein AJ, Eskin A (2005) Circadian modulation of complex learning in diurnal and nocturnal aplysia. Proc Natl Acad Sci U S A 102:12589-12594.

Lyons LC, Rawashdeh O, Eskin A (2006a) Non-ocular circadian oscillators and photoreceptors modulate long term memory formation in aplysia. J Biol Rhythms 21:245-255.

Lyons LC, Collado MS, Khabour O, Green CL, Eskin A (2006b) The circadian clock modulates core steps in long-term memory formation in aplysia. J Neurosci 26:8662-8671.

Marpegan L, Swanstrom AE, Chung K, Simon T, Haydon PG, Khan SK, Liu AC, Herzog ED, Beaulé C (2011) Circadian regulation of ATP release in astrocytes. J Neurosci 31:8342-8350.

Masri S, Sassone-Corsi P (2010) Plasticity and specificity of the circadian epigenome. Nat Neurosci 13:1324-1329.

McClung CA, Sidiropoulou K, Vitaterna M, Takahashi JS, White FJ, Cooper DC, Nestler EJ (2005) Regulation of dopaminergic transmission and cocaine reward by the clock gene. Proc Natl Acad Sci U S A 102:9377-9381.

Mirnikjoo B, Brown SE, Kim HF, Marangell LB, Sweatt JD, Weeber EJ (2001) Protein kinase inhibition by omega-3 fatty acids. J Biol Chem 276:10888-10896.

Mita R, Beaulieu MJ, Field C, Godbout R (2010) Brain fatty acid-binding protein and omega-3/omega- 6 fatty acids: mechanistic insight into malignant glioma cell migration. J Biol Chem 285:37005-37015.

Moriguchi T, Greiner RS, Salem N Jr (2000) Behavioral deficits associated with dietary induction of decreased brain docosahexaenoic acid concentration. J Neurochem 75:2563-2573.

Moriguchi T, Salem N Jr (2003) Recovery of brain docosahexaenoate leads to recovery of spatial task performance. J Neurochem 87:297-309.

Morley JE, Banks WA (2010) Lipids and cognition. J Alzheimers Dis 20:737-747.

Nishiyama H, Knopfel T, Endo S, Itohara S (2002) Glial protein S100B modulates long-term neuronal synaptic plasticity. Proc Natl Acad Sci U S A 99:4037-4042.

Novoa I, Gallego J, Ferreira PG, Mendez R (2010) Mitotic cell-cycle progression is regulated by CPEB1 and CPEB4-dependent translational control. Nat Cell Biol 12:447-456.

Owada Y, Yoshimoto T, Kondo H (1996) Increased expression of the mRNA for brain- and skin-type but not heart-type fatty acid binding proteins following kainic acid systemic administration in the hippocampal glia of adult rats. Brain Res Mol Brain Res 42:156-160.

Owada Y, Abdelwahab SA, Kitanaka N, Sakagami H, Takano H, Sugitani Y, Sugawara M, Kawashima H, Kiso Y, Mobarakeh JI, Yanai K, Kaneko K,
Sasaki H, Kato H, Saino-Saito S, Matsumoto N, Akaike N, Noda T, Kondo H (2006) Altered emotional behavioral responses in mice lacking braintype fatty acid-binding protein gene. Eur J Neurosci 24:175-187.

Panatier A, Theodosis DT, Mothet JP, Touquet B, Pollegioni L, Poulain DA, Oliet SH (2006) Glia-derived D-serine controls NMDA receptor activity and synaptic memory. Cell 125:775-784.

Pascual O, Casper KB, Kubera C, Zhang J, Revilla-Sanchez R, Sul JY, Takano H, Moss SJ, McCarthy K, Haydon PG (2005) Astrocytic purinergic signaling coordinates synaptic networks. Science 310:113-116.

Paxinos G, Franklin KBJ (2003) The mouse brain in stereotaxic coordinates, compact Ed 2. Oxford: Elsevier.

Pu L, Igbavboa U, Wood WG, Roths JB, Kier AB, Spener F, Schroeder F (1999) Expression of fatty acid binding proteins is altered in aged mouse brain. Mol Cell Biochem 198:69-78.

Raghavan AV, Horowitz JM, Fuller CA (1999) Diurnal modulation of long-term potentiation in the hamster hippocampal slice. Brain Res 833:311-314.

Rao A, Steward O (1993) Evaluation of RNAs present in synaptodendrosomes: dendritic, glial, and neuronal cell body contribution. J Neurochem 61:835-844.

Richter JD (2007) CPEB: a life in translation. Trends Biochem Sci 32:279-285.

Roth TL, Sweatt JD (2008) Rhythms of memory. Nat Neurosci 11:993-994.

Rouhana L, Wickens M (2007) Autoregulation of GLD-2 cytoplasmic poly(A) polymerase. RNA 13:188-199.

Rouhana L, Wang L, Buter N, Kwak JE, Schiltz CA, Gonzalez T, Kelley AE, Landry CF, Wickens M (2005) Vertebrate GLD2 poly(A) polymerases in the germline and the brain. RNA 11:1117-1130.

Sakai T, Tamura T, Kitamoto T, Kidokoro Y (2004) A clock gene, period, plays a key role in long-term memory formation in Drosophila. Proc Natl Acad Sci U S A 101:16058-16063.

Salem N Jr, Litman B, Kim HY, Gawrisch K (2001) Mechanisms of action of docosahexaenoic acid in the nervous system. Lipids 36:945-959.

Saper CB (2006) Staying awake for dinner: hypothalamic integration of sleep, feeding, and circadian rhythms. Prog Brain Res 153:243-252.

Saper CB, Fuller PM, Pedersen NP, Lu J, Scammell TE (2010) Sleep state switching. Neuron 68:1023-1042.

Sarov-Blat L, So WV, Liu L, Rosbash M (2000) The Drosophila takeout gene is a novel molecular link between circadian rhythms and feeding behavior. Cell 101:647-656.

Stellwagen D, Malenka RC (2006) Synaptic scaling mediated by glial TNFalpha. Nature 440:1054-1059.

Steward O, Torre ER, Tomasulo R, Lothman E (1991) Neuronal activity up-regulates astroglial gene expression. Proc Natl Acad Sci U S A 88:6819-6823.

Su G, Kintner DB, Flagella M, Shull GE, Sun D (2002) Astrocytes from $\mathrm{Na}(+)-\mathrm{K}(+)-\mathrm{Cl}(-)$ cotransporter-null mice exhibit absence of swelling and decrease in EAA release. Am J Physiol Cell Physiol 282:C1147-60.

Suh J, Jackson FR (2007) Drosophila ebony activity is required in glia for the circadian regulation of locomotor activity. Neuron 55:435-447.

Suzuki A, Stern SA, Bozdagi O, Huntley GW, Walker RH, Magistretti PJ, Alberini CM (2011) Astrocyte-neuron lactate transport is required for long-term memory formation. Cell 144:810-823.

Tanzi RE, Bertram L (2005) Twenty years of the Alzheimer's disease amyloid hypothesis: a genetic perspective. Cell 120:545-555.

Theis M, Si K, Kandel ER (2003) Two previously undescribed members of the mouse CPEB family of genes and their inducible expression in the principal cell layers of the hippocampus. Proc Natl Acad Sci U S A 100:9602-9607.

Torre ER, Lothman E, Steward O (1993) Glial response to neuronal activity: GFAP-mRNA and protein levels are transiently increased in the hippocampus after seizures. Brain Res 631:256-264.

Turek FW, Joshu C, Kohsaka A, Lin E, Ivanova G, McDearmon E, Laposky A, Losee-Olson S, Easton A, Jensen DR, Eckel RH, Takahashi JS, Bass J (2005) Obesity and metabolic syndrome in circadian clock mutant mice. Science 308:1043-1045.

Turrigiano GG (2006) More than a sidekick: glia and homeostatic synaptic plasticity. Trends Mol Med 12:458-460.

Vanguri P (1995) Interferon-gamma-inducible genes in primary glial cells of the central nervous system: comparisons of astrocytes with microglia and Lewis with brown Norway rats. J Neuroimmunol 56:35-43. 
Veerkamp JH, Zimmerman AW (2001) Fatty acid-binding proteins of nervous tissue. J Mol Neurosci 16:133-142; discussion 151-157.

Wells DG, Dong X, Quinlan EM, Huang YS, Bear MF, Richter JD, Fallon JR (2001) A role for the cytoplasmic polyadenylation element in NMDA receptor-regulated mRNA translation in neurons. J Neurosci 21:9541-9548.

Westmark CJ, Malter JS (2007) FMRP mediates mGluR5-dependent translation of amyloid precursor protein. PLoS Biol 5:e52.

Westmark PR, Westmark CJ, Jeevananthan A, Malter JS (2011) Preparation of synaptoneurosomes from mouse cortex using a discontinuous percollsucrose density gradient. J Vis $\operatorname{Exp}(55)$. pii: 3196. doi:10.3791/3196.

Wu L, Wells D, Tay J, Mendis D, Abbott MA, Barnitt A, Quinlan E, Heynen A, Fallon JR, Richter JD (1998) CPEB-mediated cytoplasmic polyadenyla- tion and the regulation of experience-dependent translation of alphaCaMKII mRNA at synapses. Neuron 21:1129-1139.

Xu LZ, Sánchez R, Sali A, Heintz N (1996) Ligand specificity of brain lipidbinding protein. J Biol Chem 271:24711-24719.

Yang Y, Ge W, Chen Y, Zhang Z, Shen W, Wu C, Poo M, Duan S (2003) Contribution of astrocytes to hippocampal long-term potentiation through release of D-serine. Proc Natl Acad Sci U S A 100:15194-15199.

Young C, Gean PW, Wu SP, Lin CH, Shen YZ (1998) Cancellation of lowfrequency stimulation-induced long-term depression by docosahexaenoic acid in the rat hippocampus. Neurosci Lett 247:198-200.

Zhong J, Zhang T, Bloch LM (2006) Dendritic mRNAs encode diversified functionalities in hippocampal pyramidal neurons. BMC Neurosci 7:17. 